\title{
Pengaruh Penerapan Model Kolaboratif MURDER terhadap Hasil Belajar, Aktivitas dan Respons Siswa dalam Pembelajaran Matematika Kelas X
}

\author{
Muawiah Inda Magfirah ${ }^{1, a)}$, Muhammad Darwis $\mathbf{M}^{1, b)}$, dan Rusli ${ }^{1, c)}$ \\ ${ }^{1}$ Jurusan Matematika FMIPA Universitas Negeri Makassar, 90224 \\ a)muawiahindahmagfirah@gmail.com \\ b) muhammaddarwis@gmail.com \\ c)rusli@unm.ac.id
}

\begin{abstract}
Abstrak. Penelitian ini bertujuan untuk mengetahui pengaruh penerapan model kolaboratif MURDER (Mood, Understand, Recall, Detect, Expand, dan Review) terhadap hasil belajar, aktivitas, dan respons siswa dalam pembelajaran matematika kelas X. Penelitian ini adalah pra-eksperimen dengan pendekatan kuantitatif dengan teknik pengambilan sampel yaitu cluster random sampling. Pengambilan data dilakukan dengan menggunakan lembar observasi keterlaksanaan pembelajaran, tes hasil belajar (pretest dan posttest), lembar observasi aktivitas siswa, dan angket respons siswa. Teknik analisis data yang digunakan adalah analisis statistika deskriptif dan inferensial. Hasil analisis statistika deskriptif menunjukkan: (1) rata-rata keterlaksanaan pembelajaran sebesar 3,73 (terlaksana dengan baik),(2) ratarata hasil pretest yaitu 35 (kategori sangat rendah). Rata-rata hasil posttest yaitu 85 (kategori tinggi), (3) hasil posttest menunjukkan bahwa ketuntasan klasikal tercapai sebesar 94\% (4) rata-rata gain ternormalisasi sebesar 0,77 (kategori tinggi), (5) rata-rata persentase aktivitas siswa sebesar 90\% (sangat aktif) (6) rata-rata persentase siswa yang memberi respons positif sebesar 89\%. Hasil analisis statistika inferensial menunjukkan: (1) nilai rata rata siswa yang diajar menggunakan model kolaboratif MURDER lebih besar dari 70, (2) nilai rata rata gain ternormalisasi lebih besar dari 0,3 (kategori sedang), (3) rata rata ketuntasan klasikal lebih besar dari 80\%. Secara umum dapat disimpulkan bahwa penerapan model kolaboratif MURDER berpengaruh terhadap hasil belajar, aktivitas, dan respons siswa dalam pembelajaran matematika kelas $X$.
\end{abstract}

Kata kunci : Hasil Belajar, Aktivitas, Respons, Model Kolaboratif MURDER, Matriks

\begin{abstract}
This study aims to determine the effect of the application of MURDER collaborative model (Mood, Understand, Recall, Detect, Expand, and Review) on student learning outcomes, activities, and responses in learning mathematics in class $X$. This research is pre-experiment with quantitative approach with techniques sampling is cluster random sampling. Data collection was carried out using observation sheets of implementation of learning, test results of learning (pretest and posttest), observation sheets of student activities, and student questionnaire responses. The data analysis technique used is descriptive and inferential statistical analysis. The results of descriptive statistical analysis showed: (1) the average of learning achievement was 3,73 (well implemented), (2) the average pretest results were 35 (very low category). The average posttest results was 85 (high category), (3) the posttest results show that classical completeness is achieved 94\% (4) the average normalized gain is 0,77 (high category), (5) the average percentage of activity students by $90 \%$ (very active) (6) the average percentage of students who gave positive response $89 \%$. The results of inferential statistics analysis show: (1) the average value of students taught using collaborative MURDER model was greater than 70, (2) the normalized gain average value was greater than 0,3 (medium category), (3) the average classical completeness greater than $80 \%$. In general it can be concluded that implementation MURDER collaborative model has an effect on students mathematics learning outcomes, activities, and responses.
\end{abstract}

Keywords: Mathematics Learning Outcomes, Activity, Response, Collaborative MURDER Model. Matrix 


\section{PENDAHULUAN}

Model pembelajaran adalah suatu tindakan pembelajaran yang mengikuti pola atau langkahlangkah pembelajaran tertentu (sintaks), yang harus diterapkan guru agar kompetensi atau tujuan belajar yang diharapkan akan tercapai dengan cepat, efektif, dan efisien (Suyitno, 2011). Dalam belajar sebaiknya guru memilih model pembelajaran yang tepat agar proses pembelajaran berjalan dengan baik. Apabila guru kurang tepat dalam memilih model pembelajaran, maka akan mempengaruhi keaktifan dan respons siswa dalam proses belajar mengajar yang mengakibatkan rendahnya hasil belajar siswa.

Guru perlu mendorong siswa agar lebih aktif serta merespon dengan baik saat proses pembelajaran sedang berlangsung. Hal tersebut dapat dilakukan dengan menjadikan suasana kelas yang lebih menyenangkan yang akan membangkitkan semangat belajar siswa. Suasana hati siswa juga menjadi salah satu faktor yang akan menimbulkan semangat belajar mereka. Oleh karena itu, guru hendaknya menggunakan suatu model untuk mengatasi hal tersebut. Salah satu model yang sesuai adalah Model kolaboratif MURDER.

MURDER adalah gabungan kata dari kata Mood (suasana hati), Understand (pemahaman), Recall (pengulangan), Detect (penemuan), Expand (Pengembangan), dan Review (pelajari kembali). MURDER membangun suasana belajar yang menyenangkan sehingga membantu siswa untuk mengikuti pembelajaran. Jika suasana belajar menyenangkan telah tercipta maka semangat dalam belajar pun akan tumbuh dan akan lebih mudah untuk mencapai tujuan pembelajaran. MURDER juga membantu siswa mengingat dan memahami apa yang telah mereka baca, dan dapat membantu proses belajar dan mengajar didalam kelas.

Penelitian ini ditunjang dengan beberapa penelitian terkait yang dilakukan sebelumnya. Elnanda (2014) meneliti tentang model collaborative MURDER berpengaruh terhadap kemampuan pemahaman konsep matematika siswa. Hasilnya menunjukkan bahwa kemampuan pemahaman konsep matematika siswa yang diajar dengan pembelajaran MURDER lebih tinggi dari pada siswa yang diajar dengan pembelajaran konvensional. Mayangsari, Suratno \& Wahono (2015) meneliti tentang pengaruh pembelajaran MURDER berbasis media interaktif flash terhadap kemampuan berpikir kritis. Hasil menunjukkan bahwa model MURDER secara signifikan berpengaruh positif terhadap kemampuan berpikir kritis siswa.

Penelitian ini berfokus pada hasil belajar, aktivitas dan respons siswa. Adapun tujuan penelitian ini adalah untuk mengetahui ada tidaknya pengaruh model kolaboratif MURDER terhadap hasil belajar, aktivitas dan respons siswa dalam pembelajaran matematika. Subjek penelitian yaitu siswa kelas X SMK. Subjek diberikan soal matematika untuk mengungkap hasil belajar siswa. Soal matematika yang diberikan adalah soal matriks.

\section{KAJIAN PUSTAKA}

Model pembelajaran adalah prosedur atau pola sistematis yang digunakan sebagai pedoman untuk mencapai tujuan pembelajaran yang didalamnya terdapat strategi, teknik, metode, bahan, media, dan alat penilaian pembelajaran (Afandi, Chamalah, \& Wardani, 2013). Banyak model pembelajaran yang dapat digunakan untuk meningkatkan hasil belajar, aktivitas dan respons siswa salah satunya yaitu model kolaboratif MURDER. Berata (2013) menyatakan bahwa model MURDER menekankan pada kemampuan siswa dalam mengkontruksi ulang informasi dan ide yang diterima, memahaminya, yang kemudian dikomunikasikan secara lisan ataupun tulisan. Sedangkan Darmika (2014) menyatakan bahwa model MURDER merupakan salah satu model pembelajaran yang dapat membangun motivasi siswa serta peningkatan kedalaman dan luas pemikiran pada siswa. Model MURDER ini merupakan singkatan dari mood (suasana hati), understand (pemahaman), recall (pengulangan), detect (penemuan), ekspand (pengembangan) dan review (pelajari kembali). 


\section{Mood (Suasana Hati)}

Langkah pertama dalam fase MURDER adalah mengatur suasana hati yang baik untuk memulai pembelajaran. Jika dimulai dengan suasana hati yang positif maka pembelajaran akan terasa mudah. Menurut Uno (2006) ranah suasan hati terbagi menjadi dua yaitu :

a. Optimisme, yaitu kemampuan untuk mempertahankan sikap positif yang realistis, terutama dalam menghadapi masa masa sulit. Dalam pengertian luas, optimisme bermakna kemampuan melihat sisi terang kehidupan dan memelihara sikap positif, sekalipun ketika berada dalam kesulitan. Optimisme mengasumsikan adanya harapan dalam cara orang menghadapi kehidupan. Optimisme adalah pendekatan yang positif terhadap kehidupan sehari-hari. Optimisme adalah lawan pesimisme, yang merupakan gejala umum depresi.

b. Kebahagiaan, yaitu kemampuan untuk mensyukuri kehidupan, menyukai diri sendiri dan orang lain, dan untuk bersemangat serta bergairah dalam melakukan setiap kegiatan. Dalam pandangan lebih luas, kebahagiaan berarti kemampuan untuk merasa puas dengan kehidupan kita, bergembira sendirian dan dengan orang lain, serta bersenang-senang.

Oleh karena itu perlu diupayakan agar proses pembelajaran merupakan proses yang meyenangkan bisa dilakukan, pertama, dengan menata ruangan yang apik dan menarik, yaitu yang memilih unsur unsur kesehatan, kedua, melalui pengelolaan yang hidup dan bervariasi yakni dengan menggunakan pola dan model pembelajaran, media dan sumber sumber yang relevan (Sanjaya, 2006). Pada langkah ini, siswa diajak untuk relaksasi atau santai yang bertujuan untuk mengatur suasana hati sebelum pembelajaran dimulai. Hal ini bisa dilakukan dengan cara memberikan semacam games dan motivasi untuk siswa.

\section{Understand (Pemahaman)}

Pemahaman adalah proses berpikir, belajar dan proses menguasai sesuatu tertentu. Menurut Carin \& Sund (Susanto, 2013) menyatakan bahwa Pemahaman merupakan kemampuan untuk menerangkan dan menginterpretasikan sesuatu, yang berarti bahwa seseorang telah memahami sesuatu atau telah memperoleh pemahaman akan mampu menerangkan atau menjelaskan kembali apa yang telah ia terima. Perlu diingat bahwa pemahaman, tidak sekedar tahu, tetapi juga menghendaki agar subjek belajar dapat memanfaatkan bahan bahan yang telah dipahami, kalau sudah demikian belajar sudah bersifat mendasar (Sardiman, 2016). Pada langkah ini, guru membagi siswa secara berkelompok dengan kemampuan yang homogen kemudian siswa diajak untuk membaca dan memahami materi yang telah disediakan oleh guru. Setiap siswa membaca bagian dengan tenang.

\section{Recall (Pengulangan)}

Mengulang adalah usaha aktif untuk memasukkan informasi kedalam ingatan jangka panjang. Mengulang suatu pekerjaan yang sudah dipelajari membuat kemampuan para siswa untuk mengingat akan semakin bertambah. Menurut Isran \& Hidayati (2016) pengulangan yaitu setelah mempelajari satu bahan dalam suatu mata pelajaran, segeralah berhenti. Setelah itu, ulangi membahas bahan pelajaran itu dengan kata kata siswa. Adapun cara mengulang yang paling sederhana yaitu sekedar mengulang dengan keras atau dengan pelan informasi yang ingin kita hafal, bahan lebih kompleks memerlukan strategi mengulang yang kompleks juga seperti menggaris bawahi ide-ide kunci dan membuat catatatan (Nadlir, 2009). Berdasarkan penjabaran tersebut, dapat disimpulkan bahwa pengulangan/Recall adalah kegiatan memanggil kembali informasi yang telah didapat sebelumnya pada siswa. Pada langkah ini siswa diajak mengingat materi tanpa melihat bacaan. Setiap anggota kelompok akan menyampaikan secara lisan pemahaman mereka dengan teman kelompoknya. 


\section{Detect (Penemuan)}

Penemuan adalah proses, cara, perbuatan menemui atau menemukan. Keberhasilan suatu proses pengajaran diukur sejauh mana siswa dapat menguasai suatu materi pelajaran yang disampaikan oleh guru (Andriani \& Utama, 2017). Untuk dapat menguasai materi siswa tidak hanya berpedoman pada satu buku, karena pada dasarnya ada berbagai sumber yang bisa dijadikan sumber untuk memperoleh pengetahuan. Pada proses ini siswa dituntut untuk menemukan suatu masalah yang dianggap sulit atau tidak dimengerti. Setelah itu siswa haruslah menemukan solusinya sendiri dengan berbagai cara. Jika siswa tersebut belum mengerti, siswa tersebut dapat bertanya dengan kelompoknya atau dengan bantuan guru.

\section{Expand (Pengembangan)}

Pengembangan adalah langkah dimana siswa mengolaborasi pengetahuan awal dan pengetahuan baru sehingga muncul akan pengembangan kemampuan berpikir dengan adanya pertanyaan "mengapa" pada diri sendiri untuk menjawab pertanyaan yang akan bisa terlihat ketika siswa berlatih untuk mengembangkan kemampuan berpikirnya (Mayangsari, dkk., 2015). Pada tahap ini siswa dituntut untuk mengembangkan materi yang telah dikuasai dengan cara mengerjakan soal yang diberikan oleh guru karena dengan pengembangan siswa akan mendapatkan informasi yang lebih banyak. Dari informasi yang telah didapat, siswa diharapkan dapat mengembangkan konsep dan juga mengaitkan dengan situasi lain berdasarkan konsep dasar pada suatu materi tertentu.

\section{Review (Pelajari Kembali)}

Review adalah pelajari kembali materi yang sudah dipelajari. Informasi informasi yang diperoleh atau materi materi yang sebelumnya sudah didapat bisa digali lagi atau diingat kembali untuk keperluan tertentu (Setiyowati \& Pramukantoro 2014). Suatu proses pembelajaran akan berlangsung dengan efektif apabila informasi yang dipelajari dapat diingat dengan baik dan terhindar dari lupa. Oleh karena itu, proses mempelajari kembali merupakan langkah untuk lebih memahami materi agar tidak mudah lupa sehingga siswa lebih mantap dan percaya diri untuk melanjutkan ke materi selanjutnya karena sudah mempunyai pengetahuan yang cukup baik pada materi sebelumnya. Pada langkah ini setiap kelompok mempresentasikan dan menyimpulkan hasil diskusi yang telah diperoleh.

Model kolaboratif MURDER memiliki kelebihan (Andriani \& Utama, 2017) yaitu:

1. Menciptakan suasana belajar yang menyenangkan .

2. Membantu para siswa dalam mengembangkan sistem belajar yang efektif dan efisien.

3. Menunjang keaktifan siswa.

Selain itu ada beberapa kelemahan dari model kolaboratif MURDER (Nurhayati, 2013) yaitu:

1. Guru mengalami kesulitan untuk mengatur peserta didik dalam kelas.

2. Peserta didik dengan pengetahuan yang kurang sulit untuk terlibat secara aktif dalam proses pembelajaran, sehingga guru melakukan pengelompokkan secara heterogen dengan tujuan agar peserta didik dengan kemampuan yang lebih dapat membantu peserta didik dengan kemampuan yang kurang.

3. Memerlukan waktu yang lama dalam proses pembelajaran.

Beberapa penelitian telah mengkaji terkait model kolaboratif MURDER. Elnanda (2014) meneliti tentang pengaruh model MURDER terhadap kemampuan pemahaman konsep matematika siswa. Dari penelitian tersebut menunjukkan nilai rata rata hasil tes kemampuan pemahaman konsep yang diajar dengan model MURDER sebesar 76,00. Sedangkan nilai rata rata hasil tes kemampuan pemahaman konsep yang diajar dengan pembelajaran konvensional sebesar 66,17. Sehingga dapat disimpulkan bahwa model MURDER lebih berpengaruh secara signifikan dibanding model konvensioanal. 


\section{METODE PENELITIAN}

Jenis penelitian yang digunakan adalah jenis penelitian pra-eksperimen dengan Desain penelitian adalah One Group - Pretest Posttest Design.

TABEL 1. Desain Penelitian Sugiyono (2008) One Group - Pretest Posttest Design

\begin{tabular}{ccc}
\hline Pretest & Treatment & Posttest \\
\hline $\mathbf{O}_{1}$ & $\mathbf{X}$ & $\mathbf{O}_{2}$ \\
\hline
\end{tabular}

Penelitian ini dilaksanakan di salah satu Sekolah Menengah Kejuruan Kota Makassar. Sampel penelitian ini terdiri dari 35 siswa dengan Teknik Cluster Random Sampling.Variabel bebas dari penelitian ini adalah model kolaboratif MURDER. Sedangkan variabel terikat yaitu hasil belajar, aktivitas siswa dan respons siswa.

Teknik pengumpulan data dilakukan dengan pemberian tes, pengisian angket, dan pengisian lembar observasi. Instrumen yang dikembangkan yaitu tes hasil belajar (pretest dan posttest), lembar observasi keterlaksanaan pembelajaran, lembar observasi aktivitas siswa, dan angket respons siswa. Instrumen telah divalidasi oleh dua validator.

Analisis data yang digunakan pada penelitian ini yaitu analisis statistik deskriptif dan analisis statistik inferensial. Analisis statistik deskriptif digunakan untuk mendeskripsikan nilai pretest, posttest, gain ternormalisasi, aktivitas dan respons. Analisis statistik inferensial digunakan untuk menguji hipotesis posttest dan gain ternormalisasi. Namun sebelumnya dilakukan uji prasyarat yaitu uji normalitas. Adapun hipotesis dalam penelitian ini yaitu rata rata hasil belajar siswa untuk (posttest) $\geq 70$, nilai gain ternormalisasi $\geq 0,3$ dan ketuntasan klasikal $\geq 80 \%$. Sedangkan untuk Aktivitas siswa $\geq 76 \%$ serta rata rata respons siswa $\geq 70 \%$.

\section{HASIL DAN PEMBAHASAN}

Penelitian dilaksanakan dengan 6 pertemuan, 1 pertemuan pemberian pretest, 1 pertemuan pemberian posttest, dan 4 pertemuan pemberian pembelajaran dengan menggunakan model kolaboratif MURDER. Pretest merupakan tes awal yang diberikan sebelum pembelajaran dilaksanakan. Sedangkan, posttest merupakan tes akhir setelah pembelajaran dilaksanakan. Selain itu, selama proses pembelajaran berlangsung dilakukan pengisian lembar observasi keterlaksanaan pembelajaran dan lembar observasi aktivitas siswa. Adapun, angket respons siswa diisi oleh siswa setelah pembelajaran dilaksanakan.

\section{Keterlaksanaan Model MURDER}

TABEL 2. Rekapitulasi Hasil Observasi Keterlaksanaan Pembelajaran

\begin{tabular}{ccccccc}
\hline \multirow{2}{*}{ Fase } & \multicolumn{4}{c}{ Pertemuan } & Rata- & \multirow{2}{*}{ Kategori } \\
\cline { 2 - 5 } & $\mathbf{1}$ & $\mathbf{2}$ & $\mathbf{3}$ & $\mathbf{4}$ & Rata & \\
\hline Pendahuluan & 3,4 & 3,6 & 3,8 & 4 & 3,7 & Baik \\
Kegiatan Inti & 3,75 & 4 & 3,82 & 3,75 & 3,83 & Baik \\
Penutup & 3,5 & 3,75 & 3,5 & 4 & 3,68 & Baik \\
\hline Rata-rata & 3,55 & $3,7 \varepsilon$ & 3.71 & 3,91 & 3,74 & Baik \\
\hline
\end{tabular}

Tabel 2 menunjukkan bahwa pada fase pendahuluan setiap pertemuan mengalami peningkatan dari pertemuan pertama 3,4 hingga pertemuan terakhir 4. Hal tersebut dikarenakan siswa sudah mulai terbiasa dengan tahap pendahuluan yaitu mood dimana guru memberikan games agar siswa merasa nyaman dalam belajar. Secara keseluruhan skor rata-rata keterlaksanaan pembelajaran yaitu 3,74 (terlaksana dengan baik). 


\section{Hasil Belajar Siswa}

Analisis Deskriptif

TABEL 3. Rekapitulasi Nilai Pretest Siswa

\begin{tabular}{lc}
\hline Statistik & Nilai \\
\hline Ukuran Sampel & 35 \\
Rata-rata & 35 \\
Median & 40 \\
Modus & 20 \\
Standar Deviasi & 16,9 \\
Variansi & 284,5 \\
Rentang skor & 50 \\
Skor terendah & 10 \\
Skor tertinggi & 60 \\
\hline
\end{tabular}

Tabel 3 menunjukkan bahwa skor rata-rata hasil belajar siswa sebelum penerapan model kolaboratif MURDER adalah 35 dengan skor ideal 100. Dengan kata lain, Skor rata rata menunjukkan bahwa hasil pretest siswa masih tergolong sangat rendah. Skor yang dicapai siswa tersebar dari skor terendah 10 sampai dengan skor tertinggi 60 dengan rentang 50.

TABEL 4. Distribusi dan Persentase Nilai Pretest Siswa

\begin{tabular}{|c|c|c|c|}
\hline Nilai siswa & Kategori & Frekuensi & Persentase (\% \\
\hline $90-100$ & Sangat tinggi & 0 & 0 \\
\hline $80-89$ & Tinggi & 0 & 0 \\
\hline $65-79$ & Sedang & 0 & 0 \\
\hline $55-64$ & Rendah & 5 & 14,3 \\
\hline $0-54$ & Sangat rendah & 30 & 85,7 \\
\hline & nlah & 35 & $100 \%$ \\
\hline
\end{tabular}

Tabel 4 menunjukkan bahwa 100\% ketuntasan klasikal siswa yang tidak memenuhi ketuntasan individu. Hal ini dapat dilihat dari nilai siswa yang hanya berada pada rentang (0-54) dan (55-64). Sehingga, skor rata-rata hasil belajar siswa sebelum diajar model kolaboratif MURDER berada pada kategori "sangat rendah".

TABEL 5. Rekapitulasi Nilai Posttest Siswa

\begin{tabular}{lc}
\hline Statistik & Nilai \\
\hline Ukuran Sampel & 35 \\
Rata-rata & 85 \\
Median & 90 \\
Modus & 90 \\
Standar Deviasi & 12,4 \\
Variansi & 154,9 \\
Rentang skor & 40 \\
Minimum & 60 \\
Maksimum & 100 \\
\hline
\end{tabular}

Tabel 5 menunjukkan bahwa skor rata-rata hasil belajar siswa setelah penerapan model kolaboratif MURDER adalah 85 dengan skor ideal 100. Skor rata rata tersebut berada pada kategori tinggi. Hal ini dapat dilihat dari nilai tertinggi 100 dengan modus atau nilai yang sering muncul 90 yang berarti bahwa sebagian besar siswa telah mengerti atau paham dengan materi yang diajarkan.

Tabel 6 menunjukkan bahwa ketuntasan klasikal terpenuhi dengan 94,3\% siswa yang mencapai ketuntasan individu. Nilai 94,3 diperoleh dari persentase kategori sangat tinggi, tinggi dan 
sedang. Sehingga, disimpulkan skor rata rata hasil belajar siswa setelah diajar dengan menggunakan model kolaboratif berada pada kategori "sangat tinggi".

TABEL 6. Distribusi dan Persentase Nilai Posttest Siswa

\begin{tabular}{|c|c|c|c|}
\hline Nilai siswa & Kategori & Frekuensi & Persentase $(\%$ \\
\hline $90-100$ & Sangat tinggi & 18 & 51,4 \\
\hline $80-89$ & Tinggi & 8 & 22,9 \\
\hline $65-79$ & Sedang & 7 & 20 \\
\hline $55-64$ & Rendah & 2 & 5,7 \\
\hline $0-54$ & Sangat rendah & 0 & 0 \\
\hline \multicolumn{2}{|c|}{ Jumlah } & 35 & $100 \%$ \\
\hline
\end{tabular}

TABEL 7. Rekapitulasi Peningkatan Hasil Belajar Siswa

\begin{tabular}{lc}
\hline \multicolumn{1}{c}{ Statistik } & Nilai \\
\hline Ukuran Sampel & 35 \\
Rata-rata & 0,77 \\
Median & 0,77 \\
Modus & 1 \\
Standar Deviasi & 0,18 \\
Variansi & 0,03 \\
Rentang skor & 0,60 \\
Minimum & 0,4 \\
Maksimum & 1 \\
\hline
\end{tabular}

Tabel 7 menunjukkan bahwa kelas yang diajar memperoleh rata-rata peningkatan hasil belajar sebesar 0,77 dengan rata-rata pretest 35 dan rata-rata posttest 85 . Rata rata peningkatan hasil belajar siswa menunjukkan peningkatan dari sangat rendah ke tinggi. Modus 1 berarti kebanyakan siswa mengalami peningkatan dalam belajar matematika setelah penerapan model MURDER.

TABEL 8. Klasifikasi Gain Ternormalisasi Pada Kelas Yang Diajar Menggunakan Model Kolaboratif MURDER

\begin{tabular}{|c|c|c|c|}
\hline $\begin{array}{l}\text { Koefisien Gain } \\
\text { Ternormalisasi }\end{array}$ & Jumlah Siswa & Persentase & Klasifikasi \\
\hline$g<0,3$ & 0 & $0 \%$ & Rendah \\
\hline $0,3 \leq g<0,7$ & 12 & $34 \%$ & Sedang \\
\hline$g \geq 0,7$ & 23 & $66 \%$ & Tinggi \\
\hline Jumlah & 35 & $100 \%$ & \\
\hline Rata-rata & 0,7 & & Tinggi \\
\hline
\end{tabular}

Tabel 8 menunjukkan bahwa terdapat 12 siswa atau $34 \%$ berada pada kategori sedang dan 23 siswa atau $66 \%$ berada pada kategori tinggi. Tidak ada satupun siswa yang berada pada kategori rendah. Berdasarkan rata-rata pretest siswa, maka rata rata peningkatan hasil belajar siswa dihitung dengan rumus gain ternormalisasi sebesar 0,77 . Hal ini berarti peningkatan hasil belajar siswa yang diajar menggunakan model kolaboratif MURDER berada pada kategori tinggi.

\section{Analisis Inferensial}

Pada analisis inferensial, berdasarkan uji normalitas untuk posttest siswa diperoleh $p$-value $>\alpha$ yaitu 0,302 $>0,05$. Peningkatan (nilai gain) siswa diperoleh $p$-value $>\alpha$ yaitu $0,065>0,05$. Hal ini menunjukkan bahwa data hasil posttest dan data peningkatan (nilai gain) berasal dari populasi yang berdistribusi normal.

Selanjutnya dilakukan pengujian hipotesis: 
Tabel 9 menunjukkan bahwa Sig.(2-tailed) untuk data posttest adalah 0,000. Jika digunakan $\alpha=0,05$ maka diperoleh $p$-value $<\alpha$. Ini berarti bahwa untuk rata rata hasil belajar siswa (posttest) setelah penerapan model kolaboratif MURDER lebih besar atau sama dengan 70.

TABEL 9. Hasil Uji-t Satu Sampel Posttest

\begin{tabular}{llcc}
\hline & & \multicolumn{2}{c}{ Nilai Uji (Test Value) $=\mathbf{7 0}$} \\
\hline & T & Df & Sig. (2-tailed) \\
\hline Posttest & 6,925 & 34 & 0,000 \\
\hline
\end{tabular}

TABEL 10. Hasil Uji-t Satu Sampel Gain Ternormalisasi

\begin{tabular}{cccc}
\hline & \multicolumn{3}{c}{ Nilai Uji (Test Value) = 0,3 } \\
\hline & T & Df & Sig. (2-tailed) \\
\hline Gain ternormalisasi & 15,391 & 34 & 0,000 \\
\hline
\end{tabular}

Tabel 10 menunjukkan bahwa Sig.(2-tailed) untuk data gain ternormalisasi adalah 0,000. Jika digunakan $\alpha=0,05$ maka diperoleh $p$-value $<\alpha$. Ini berarti bahwa untuk Peningkatan hasil belajar siswa yaitu skor rata-rata posttest lebih tinggi daripada skor rata-rata pretest (rata-rata gain ternormalisasi melebihi 0,3 ).

TABEL 11. Statistik Uji-Z Ketuntasan Klasikal

\begin{tabular}{ccc}
\hline & $\mathbf{Z}_{\text {hitung }}$ & $\mathbf{Z}_{\text {tabel }}$ \\
\hline Ketuntasan Klasikal & 2,07 & 1,96 \\
\hline
\end{tabular}

Tabel 11 menunjukkan bahwa $Z_{\text {hitung }}=2,07$ dan $Z_{\text {tabel }}=1,96$ maka diperoleh $Z_{\text {hitung }}>$ $Z_{\text {tabel }}$. Hal ini menunjukkan bahwa siswa mencapai ketuntasan belajar dengan menggunakan model kolaboratif MURDER secara klasikal lebih besar atau sama dengan $80 \%$.

\section{Aktivitas Siswa}

TABEL 12. Rekapitulasi Hasil Observasi Aktivitas Siswa

\begin{tabular}{|c|c|c|c|c|c|c|c|}
\hline \multirow{2}{*}{$\begin{array}{l}\text { Aspek yang } \\
\text { diobservasi }\end{array}$} & \multicolumn{4}{|c|}{$\begin{array}{l}\text { Skor rata-rata aktivitas } \\
\text { siswa setiap pertemuan }\end{array}$} & \multirow{2}{*}{\multicolumn{2}{|c|}{$\begin{array}{l}\text { Rata- Persentase } \\
\text { Rata Per Aspek }\end{array}$}} & \multirow[t]{2}{*}{ Kategori } \\
\hline & 1 & 2 & 3 & 4 & & & \\
\hline 1 & 4 & 4 & 4 & 4 & 4 & $100 \%$ & Sangat Aktif \\
\hline 2 & 4 & 4 & 4 & 4 & 4 & $100 \%$ & Sangat Aktif \\
\hline 3 & 2 & 4 & 4 & 3 & 3,25 & $81 \%$ & Aktif \\
\hline 4 & 3 & 4 & 4 & 4 & 3,75 & $94 \%$ & Sangat Aktif \\
\hline 5 & 3 & 3 & 4 & 4 & 3,5 & $88 \%$ & Sangat Aktif \\
\hline 6 & 3 & 3 & 4 & 4 & 3,5 & $88 \%$ & Sangat Aktif \\
\hline 7 & 3 & 3 & 3 & 3 & 3 & $75 \%$ & Cukup Aktif \\
\hline 8 & 4 & 4 & 3 & 4 & 3,75 & $94 \%$ & Sangat Aktif \\
\hline 9 & 3 & 3 & 3 & 4 & 3,25 & $81 \%$ & Aktif \\
\hline 10 & 4 & 3 & 4 & 4 & 3,75 & $94 \%$ & Sangat Aktif \\
\hline 11 & 3 & 4 & 3 & 3 & 3,25 & $81 \%$ & Aktif \\
\hline 12 & 3 & 4 & 3 & 3 & 3,25 & $81 \%$ & Aktif \\
\hline 13 & 4 & 4 & 4 & 4 & 4 & $100 \%$ & Sangat Aktif \\
\hline 14 & 4 & 4 & 4 & 4 & 4 & $100 \%$ & Sangat Aktif \\
\hline Rata-rata & 3,35 & 3,64 & 3,64 & 3,71 & 3,58 & $90 \%$ & Sangat Aktif \\
\hline Persentase Pertemu & $84 \%$ & $91 \%$ & $91 \%$ & $93 \%$ & $90 \%$ & & Sangat Aktif \\
\hline
\end{tabular}

Tabel 12 menunjukkan bahwa untuk aspek 7 berada pada kategori cukup aktif dan sebagian besar aspek lainnya berada pada kategori aktif dan sangat aktif. Hal ini terjadi karena siswa sudah terbiasa dengan aktivitas MURDER. Selanjutnya persentase rata-rata untuk semua pertemuan yaitu $90 \%$ (sangat aktif). Dimana persentase rata rata aktivitas siswa lebih besar dari $76 \%$. 


\section{Respon Siswa}

TABEL 13. Data Angket Respon Siswa

\begin{tabular}{|c|c|c|c|}
\hline \multirow{2}{*}{$\begin{array}{c}\text { Aspek yang } \\
\text { direspon }\end{array}$} & \multicolumn{2}{|c|}{ Respons Siswa } & \multirow{2}{*}{ Persentase Posi } \\
\hline & $\mathbf{Y a}$ & Tidak & \\
\hline 1 & 33 & 2 & $94 \%$ \\
\hline 2 & 33 & 2 & $94 \%$ \\
\hline 3 & 28 & 7 & $80 \%$ \\
\hline 4 & 32 & 3 & $91 \%$ \\
\hline 5 & 31 & 4 & $89 \%$ \\
\hline 6 & 28 & 7 & $80 \%$ \\
\hline 7 & 32 & 3 & $91 \%$ \\
\hline 8 & 30 & 5 & $86 \%$ \\
\hline 9 & 33 & 2 & $94 \%$ \\
\hline 10 & 31 & 4 & $89 \%$ \\
\hline Rata-rata & 31,1 & 3,9 & $89 \%$ \\
\hline
\end{tabular}

Tabel 13 menunjukkan bahwa terdapat 3 aspek pernyataan yang paling direspons positif oleh siswa yaitu aspek 1, 2 dan 9. Hal ini terjadi karena model kolaboratif MURDER dapat menghilangkan rasa bosan saat belajar dan merasa puas serta siswa merasa setuju apabila model pembelajaran kolaboratif MURDER diterapkan pada mata pelajaran lain.

Selanjutnya dapat dilihat bahwa persentase rata-rata siswa yang memberi respons positif terhadap model kolaboratif MURDER sebesar 89\%. Dimana persentase rata-rata siswa yang memberi respons positif lebih besar dari $70 \%$ siswa.

\section{KESIMPULAN}

Kesimpulan yang diperoleh dari penelitian ini yaitu model kolaboratif MURDER berpengaruh terhadap hasil belajar, aktivitas dan respons siswa dalam pembelajaran matematika kelas X. Hal ini dapat dilihat dari hasil belajar matematika siswa setelah diajar menggunakan model kolaboratif MURDER yang menunjukkan bahwa skor rata-rata 85 dari skor minimal 70 . Sebanyak 94,3\% siswa mencapai ketuntasan individu, artinya ketuntasan belajar secara klasikal tercapai. Dan nilai skor rata-rata gain ternormalisasi siswa sebesar 0,77 (tinggi). Selain itu, skor rata-rata aktivitas siswa sebesar $90 \%$ (sangat aktif). Serta rata-rata persentase siswa yang memberi respons positip terhadap penerapan model kolaboratif MURDER sebesar 89\%.

Masih ada beberapa hal menarik yang dapat diteliti selanjutnya. Penelitian ini hanya mengukur dua variabel. Variabel terikat yaitu model MURDER dan variabel bebas yaitu hasil belajar, aktivitas dan respons. Variabel lain yang dapat dikembangkan yaitu prestasi, kemampuan berpikir kritis, dan pemecahan masalah. Selain itu, dapat diterapkan pada materi pembelajaran lainnya sebagai penelitian lanjutan dalam penelitian ini.

\section{DAFTAR PUSTAKA}

Afandi, M., Chamalah, E., \& Wardani, O. P. (2013). Model dan Metode Pembelajaran di Sekolah. Semarang: Unissula Press.

Andriani, S., \& Utama, W. (2017). Pengaruh Model Pembelajaran Kolaboratif MURDER Terhadap Kemampuan Berpikir Kritis Matematis Siswa. Seminar Matematika dan Pendidikan Matematika UNY.

Berata, I. N. (2013). Pengaruh Model Cooperative Learning Type MURDER With Metecognitive Scaffolding (CLMMS) Terhadap Hasil Belajar. 
Darmika. (2014). Pengaruh Model Pembelajaran Kooperatif MURDER Terhadap Motivasi Belajar dan Prestasi Belajar. E-jurnal Program Pascasarjana Universitas Pendidikan Ganesha,4.

Elnanda, R. (2014). Pengaruh Model Pembelajaran Collaborative MURDER Terhadap Kemampuan Pemahaman Konsep Matematika Siswa (Skripsi). Universitas Islam Negeri Syarif Hidayahtullah Jakarta, Tangerang.

Isran, \& Hidayati. (2016). Pengaruh Model Pembelajaran MURDER (Mood, Understand, Recall, Digest, Expand, Review) Terhadap Hasil Belajar. Jurnal Ilmiah Pendidikan, 3(1).

Mayangsari, P. W., Suratno, \& Wahono, B. (2015). Pengaruh Stategi Pembelajaran MURDER (Mood, Understand, Recall, Digest, Expand, Review) Berbasis Interaktif Flash Terhadap Kemampuan Berpikir Kritis, Metakognisi Dan Pencapaian Hasil Belajar Siswa. Jurnal Edukasi UNEJ, 2(2).

Nadlir. (2009). Psikologi Belajar. Jakarta: UIN Press.

Nurhayati, A. (2013). Keefektifan Teknik MURDER Dalam Pembelajaran Keterampilan Membaca

Peserta Didik Kelas IX SMA Negeri 1 Ngaglik Sleman (Skripsi). Universitas Negeri Yogyakarta, Yogyakarta.

Sanjaya, W. (2006). Strategi Pembelajaran Berorientasi Standart Proses Pendidikan. Jakarta: Kencana Prenada Media.

Sardiman. (2016). Interaksi dan Motivasi Belajar Mengajar . Jakarta: PT. Raja Grafindo.

Setiyowati, E. A., \& Pramukantoro, J. A. (2014). Model Pembelajaran Kooperatif MURDER Untuk Meningkatkan Hasil Belajar Siswa. Jurnal Pendidikan, 3(1).

Susanto, A. (2013). Teori Belajar dan Pembelajaran di Sekolah Dasar. Jakarta: Kencana Prenada Media Group.

Suyitno, A. (2011). Dasar-dasar dan Proses Pembelajaran Matematika I. Semarang: Universitas Negeri Semarang.

Uno, H. B. (2006). Orientasi Baru Dalam Psikologi Pembelajaran. Jakarta: PT Bumi Aksara. 